\title{
LO ANIMAL Y LO SAGRADO SEGÚN TRES POEMAS DE LA ENCICLOPEDIA DE MARAVILLAS DE LAUREANO ALBÁN
}

The animal and the sacred through three poems of the wonderful encyclopedia by Laureano Albán

\section{Ronald Campos López*}

\begin{abstract}
RESUMEN
Este artículo analiza las experiencias del sujeto lírico de la Enciclopedia de maravillas de Laureano Albán, respecto del misterio de lo sagrado a partir de la contemplación de criaturas como el buey, la gaviota y el lobo en los poemas homónimos.

Palabras clave: Literatura costarricense, poesía, misterio tremendo y fascinante, lo sagrado, lo animal.
\end{abstract}

\section{ABSTRACT}

The experiences of Laureano Albán Enciclopedia de maravillas lyrical subject, respect the mystery of the sacred, are analyzed according to the contemplation of creatures like the ox, the seagull and the wolf in homonyms poems.

Key Words: Costa Rican literature, poetry, tremendous and fascinating mystery, the sacred, the animal. 


\section{Horizonte de lectura}

Desde la década de los 60 hasta la actualidad, la obra de Laureano Albán ha sido reconocida como una de las más personales y de ruptura de la poesía costarricense. Dentro de esta trayectoria, la Enciclopedia de maravillas ocupa un lugar destacado por constituir un patrimonio único en la poesía y literatura universales, donde la diversidad temática y estilística, la capacidad subjetiva de creación poética y la perspectiva trascendentalista son notorios cuantitativa $\mathrm{y}$ cualitativamente.

La imaginación creadora y simbólica del sujeto lírico en Enciclopedia de maravillas recurren, significativamente, a los animales como referentes líricos, en tanto se busca la exaltación del mysterium tremendum et fascinans de lo sagrado (Otto, 1925; Eliade, 1981) y la conversión poética del mundo en una regeneración metafórica de las realidades como propuestas de acercamientos entre el ser, la naturaleza y la intuición numinosa, puesto que, como expresa Chinchilla "lo sagrado no se revela si no es a través de lo natural" (2010: 101). En definitiva, se responde así al concepto de hierofanía.

Por eso, se pretende demostrar tal aserto, analizando "El buey", "El lobo" y "La gaviota", ya que a través de estos motivos animales el sujeto lírico intuye y reconoce manifestaciones de lo sagrado en medio del mundo profano.

\section{2. "El buey"}

Y cuando yo estoy solo

y me quema la sed,

la sed de haber nacido

con parte de mi frente

vencida por la vida.

Y cuando alzo los ojos

con la terneza herida

del que quiere volar

y está anclado a sus manos.

Y cuando oso mirar más allá,

hacia las tretas agudas del destino.

¿En dónde, cuándo, cómo cesarán las estrellas

en mis ojos dormidos?

Y cuando siento atrás,

donde golpea la brisa

del ayer, en mi cuello,

la pesadez del yugo

de todo lo que sé,

ingobernablemente

heridor de mi vida.

Y cuando grito a Dios

desde el fondo de todos

los ojos agoreros del olvido,

y Él, que es y no es

la pregunta que sabe

la respuesta perdida,

me mira largamente

desde la última estrella

de polvo de la tarde,

y se vuelve a dormir,

ciego de lejanías.

$\mathrm{Y}$ cuando fui a la tierra

a devolver la sombra

de polvo de mi abuelo,;

que fue un cedro entre todos,

aprendiz de raíces.

Y regresé de nuevo

a dejar a mi hermano poeta

y a la tía que me heredó la risa,

$\mathrm{y}$ al vecino y a tantos,

y la tierra tan sólo [sic]

devoró, inmotivada,

sus largos corazones de semilla.

Y cuando alzo las manos,

diariamente nacidas,

y me enfrento a la arena

roja de cada día, necesidad azul

que en la sangre de todos

encadena raíces.

Te entiendo[,] $]^{1}$ compañero, buey del ayer que pasas,

subidor de mi infancia,

entre el barro y la niebla

que en los ojos te humillan.

(Albán, 1995: 192)

El sujeto lírico comienza expresando su estado solitario en este texto. Su soledad conlleva al autodescubrimiento de esas necesidades 
existenciales ("la sed"), enfatizadas mediante la anadiplosis en los versos 2 y 3; esas necesidades de obtener respuestas ante esa contingencia racional, alejada de cualquier experiencia sagrada (vv. 3-5). La "frente" connota, en estos primeros versos, un acto reflexivo, más que intuitivo, del sujeto lírico sobre su "vida" y en general.

Este acto reflexivo lleva a este sujeto a unir su deseo de "volar" a lo anterior, a través de la conjunción coordinante copulativa " $y$ ". $\mathrm{Su}$ avidez de vuelo representa, precisamente, la "sed" de desprenderse de los valores profanos y racionales del mundo para establecer, así, una relación más significativa entre lo celestial y lo terrenal en términos de un estado espiritual comprometido con la búsqueda iniciática de lo sagrado. Por eso, el sujeto lírico eleva sus "ojos" (vv. 6-9), pues ellos simbolizan la esperanza de percibir en el ámbito celestial una hierofanía o bien una kratofanía.

La cualidad de lo tierno, asociado a la mirada (los "ojos"), sugiere el deseo de este sujeto por alcanzar un nivel de conciencia más intuitiva sobre el pensamiento meramente racional al que está atado, a través de los trabajos materiales y racionales propios de los condicionamientos espaciotemporales de las necesidades de supervivencia en el plano físico ("manos"). En este sentido pueden interpretarse los nueve primeros versos del poema.

El deseo de "volar" conduce al sujeto lírico a "mirar más allá"; a "mirar" a las "estrellas", precisamente. Estas representan su deseo de trascender la tierra y conocer allende lo racional (v. 14), acceder a la iluminación mística, ascender "hasta el estado de astros celestes $[\ldots \mathrm{y} . .$.$] situarse en los grandes ritmos$ cósmicos y armonizarse con ellos" (Chevalier y Gheerbrant, 1988: 484, 488). Es en medio de este movimiento ascensional, cuando este sujeto intenta apenas acercarse ("mirar") a "las tretas agudas del destino".

El conocimiento racional profano del sujeto lírico constituye una carga pesada y atadura (vv. 18-19) que hiere, inclusive, su "vida" cuando él desea trascender o al menos percibir lo sagrado en su existencia y el mundo para, así, sacralizar su espacio y vivencias $\mathrm{y}$, en consecuencia, superar el dominio del tiempo (v. 16-17) que lo sujeta y obliga a obedecer una naturaleza fenomenológica y trágica de la "vida".

En este planteamiento, se evidencia el "yugo", en tanto "símbolo de avasallamiento, opresión y coacción" (Chevalier y Gheerbrant, 1988: 1081); es, precisamente, el conocimiento racional la causa de esta coartación del sujeto lírico ante la "vida". Sin embargo, simbólicamente, él se somete a otro "yugo". $\mathrm{Si}$ "todo lo que sé" racionalmente lo avasalla, él mismo se ha sometido al "yugo" de la meditación, del "olvido" de lo consciente, de la armonización que busca "unificar el ser, tomar conciencia y realizar, finalmente, la única Unión verdadera: la del alma con Dios" (Chevalier y Gheerbrant, 1988: 1081). Por eso, el sujeto lírico grita (vv. 22-24). Su "yugo", ahora, se dirige a osar "mirar" con el "ojo" intuitivo ${ }^{2}$.

No obstante, el "grito" del sujeto lírico ante "Dios" - su "grito" resulta una optación simultáneamente por deseo vehemente y deprecación- parece no ser atendido. En el momento cuando este sujeto suplica para que sea "Él" quien lo ampare, pues su "grito" viene de ese "yugo", de esa visión suprahumana que intuye, que late ya con fuerza desde su interior, deseosa de olvidar el conocimiento racional (vv. 23-24) y sustituir este por un saber intuitivo que conlleve alcanzar la trascendencia por la mejor vía ("ojos agoreros"). En ese momento su "grito", que es la necesidad ("sed") de adquirir el Saber numinoso y su presencia e incorporarlos en su persona, resulta fallido. "Dios" es para el sujeto lírico un ente antitético, incomprensible y omnisapiente (vv. 25-27).

A pesar de que "Él" es el Saber absoluto y puede responder a la súplica y existencia trágica de este sujeto y propiciarle la ascensión espiritual, solo se detiene un instante a escuchar su "grito". "Él” mismo ahora se vuelve "olvido", no el deseado por el sujeto lírico, sino el que reafirma a este último su soledad, fugacidad y pérdida en la dimensión del tiempo (vv. 29-30) y el espacio en donde parece perderse Dios, "ciego de lejanías". 
En este momento de soledad (v. 1), preso de la dimensión temporal y el combate inevitable que representa la existencia cotidiana y profana, el sujeto lírico rememora la "muerte". Él es incapaz de olvidar; Él lleva en su saber consciente el ejemplo de los estragos de la "tierra". Esta última, se presenta para este sujeto como el caos y la oscuridad ${ }^{3}$. Se retoma del simbolismo la "tierra" por su carácter destructivo, pues ella ha devorado a su "abuelo", a su "hermano poeta", a su "tía", a su "vecino" y "a tantos". Todos estos se encuentran en un mismo nivel de importancia según la enunciación del sujeto lírico, pues ellos eran personas enérgicas, vitales y nobles; considérese al "abuelo" metonimia de las personas mencionadas anteriormente y su relación simbólica con los atributos del "cedro"4.

Los versos 42-44 remiten al arquetipo de la tellus mater, la madre que da la vida y la devora. El sujeto lírico fue a "devolverle" a la "tierra" "la sombra/ de polvo" en que se convirtió cada uno de sus seres queridos o conocidos. Él es consciente de que él mismo llegará, irremediablemente, a ser tal "sombra"; porque, aunque todos tuvieron "corazones de semilla", siempre murieron. Aquí toma fuerza el simbolismo de la "semilla"5. Esta, si bien connota los ciclos de vida y muerte, también sugiere, mediante su coincidentia oppositorum, la posibilidad de resurgir desde el mundo terrenal-subterráneo hacia la vida plena en la luz; esto es, el cambio anhelado "del que quiere volar".

En síntesis, el recuerdo, los simbolismos de la "tierra" y la "semilla" solo reafirman en el sujeto lírico la posibilidad de que esa "sed", ese "volar", ese "olvido" de la primacía de lo racional sean "semilla" fecunda y den paso a la obtención de un saber intuitivo y suprasensible. Es decir, posibilidad de renacer, de alcanzar una regeneración para comenzar un nuevo ciclo.

Por eso, en los más desolados y desconcertantes momentos de su vida, continúa cantando el sujeto lírico (vv. 45-50). Los trabajos ("manos") y vivencias cotidianas ("diariamente nacidas") le proporcionan al sujeto lírico experiencias intuitivas que lo llevan, de la manera más devota e íntima, a una expresión corporal y simbólica ${ }^{6}$ (vv. 6 y 45 ) de ese estado de imploración (v. 22), angustia (vv. 7-8) y reclamo (vv. 28-32). El sujeto lírico adopta este gesto corporal frente a la existencia trágica que se reafirma una vez más. Ahora, a través, primero, de esa "arena" terrenal, fugaz y engañosa por su carácter dúctil e inestable, esa "arena de los conflictos de la conciencia en el ser humano" (Diel, 1976: 37); y, segundo, de lo rojo del crepúsculo ${ }^{7}$ que rivaliza lo inmanente y lo trascendente de la tierra al cielo.

El sujeto lírico sabe que permanecer viviendo en una realidad profana y desacralizada significaría continuar con el intento imposible de "todos" de, en el fondo, apresar (vv. 48-50), aprehender el tiempo (vv. 47-48), engañosamente ("arena"). Pero, precisamente, los versos que siguen expresan la mirada de este sujeto hacia lo trascendente, hacia eso que rompe la realidad profana.

Hasta este punto, el modelo compositivo del poema responde a un esquema sintético ${ }^{8}$ (López-Casanova, 1994). Todas las afirmaciones enunciadas desde el verso 1 hasta el 50 se hilan por medio de la anáfora y la conversión ("Y cuando"), para dar paso a la base condensadora: La identificación del sujeto lírico con el "buey" debido al pathos de su existencia.

En los últimos versos del poema, el apóstrofe logra evidenciar la autoidentificación y homologación del sujeto lírico con el "buey", puesto que ambos comparten la misma sujeción temporal: el "buey" también es un recuerdo (vv. 52-53); aquel se encuentra como esta criatura lírica también domeñado al tiempo, sin voluntad en lo terrenal y profano, dentro de una lógica racional de pensamiento (vv. 54-55). El sujeto lírico llega a ser consciente de esto (vv. 18-19) ahora, "cuando" es el momento presente de los dos, pues - tal como lo permiten leer las figuras de dicción por repetición (anáfora y conversión) - ambos están solos, alzan los ojos, osan mirar más allá, sienten el pasado atrás, gritan a Dios, van a la tierra, alzan las manos. La conjunción coordinante copulativa "y" que abre cada anáfora y conversión sugiere la existencia de otras situaciones anteriores o razones previas que el sujeto lírico y el "buey" 
también comparten, pero que para efectos del poema no han sido enunciadas.

El sujeto lírico, ergo, es como un "buey" y este, como un ser humano trágico como aquel. Simbólicamente, "la figura del buey marca la fuerza y la potencia, el poder de abrir surcos intelectuales para recibir las lluvias fecundas del cielo" (Pseudo-Dionisio, 1943: 242). Así como este sujeto se encuentra bajo el "yugo" del conocimiento racional que le impide acceder a un estado intuitivo pleno, el "buey" está bajo el "yugo" de la labranza (vv. 54-55). Pero, así como el "yugo" simboliza para el sujeto lírico el estado de meditación y unificación con lo numinoso, de igual manera la criatura lírica como su "compañero" se enfrenta a lo indeterminado, incierto y caótico de la existencia ("niebla"), (a)guardando en sus "ojos" la posibilidad de reivindicación de su mundo y condición profana, simbolizada en la coincidentia oppositorum de la "niebla". Este último símbolo connota tanto la confusión en el tránsito temporal de la existencia, como el preludio de las revelaciones y manifestación sagradas.

No obstante, existe una significativa y rotunda diferencia entre ambos. El "buey" es simplemente una bestia, y el sujeto lírico, contemplándola, es capaz de trascender su propia naturaleza física al experimentar la aprehensión del mysterium tremendum y el paso desde lo profano hacia lo sagrado; experiencias que esta criatura lírica no puede vivir.

El pathos o destino trágico del "buey" del texto albaniano no se circunscribe y delimita determinantemente al yugo de las labores agrícolas, ganaderas, comerciales o contingentes, como ocurre en otros textos de la literatura costarricense (Campos, 2013). Lo trágico de la figura del "buey" en la Enciclopedia de maravillas se orienta hacia la identificación, la mostración y la revelación de una existencia, un saber y una plenitud intuitiva y trascendental que involucra a todo ser humano, no únicamente a un campesino, un oligarca o un pueblo específico (Campos, 2013), en medio del "yugo" simbólico que es su autoconocimiento, autoidentificación, compromiso, fe y perseverancia con la empresa cotidiana de unificarse espiritualmente con lo cósmico, lo numinoso y darle respuestas a la vida, desde la vivencia plena de lo sagrado, y no solo desde la dimensión de las experiencias terrenales y profanas. Así puede comprobarse en los versos 1, 6, 10, 15, 18, 19, 22-33, 45 y 51-55.

En definitiva, en el poema de Albán se presenta un "buey" trágico, no porque acepte y se someta a la adversidad de las realidades contingentes como se ha demostrado en los textos de la literatura costarricense (Campos, 2013), sino porque busca cohesionar ("subidor") en su ser, como el sujeto lírico, lo profano, lo terrestre y lo racional ("barro") con lo sagrado, lo celestial e intuitivo ("más allá"), con miras, como se mencionó antes, a una meditación y unificación con lo numinoso, a través de la incertidumbre y el caos que es la existencia.

\section{3. "La gaviota"}

Qué alta la gaviota, madre, sobre la arena, como espejo que tiene casa en todos los sueños. Llámala, madre, dile que yo también soy viento. Que vengo de tu nombre como viento del tiempo. No la dejes que huya al azul invencible, a la terrible nieve que se incendia en las tardes. Que yo quiero aprender el nombre que ella sabe de todas las estrellas.

Y la segura luz que la sostiene en vilo sobre todas las muertes. Que venga, que juguemos blancos juegos, ¡tan cómplices ella y yo ante los mares! Que si viene, prometo ay, dejarle mi sombra, ésta que tú inventaste amarrada a tu sombra. loca de lejanías, 
ciega de lejanías

como todos los dioses.

Dile que venga, madre,

a jugar con mis sombras,

con los trajes inmensos

que me cubren el alma.

Que no vuelvo a llorar

en las noches de luna,

que seré para siempre

la lámpara que busca.

Llámala, madre, mira

que está azul y desnuda,

cada vez más lejana

como rosa en invierno.

Que si sigue subiendo,

y yo aquí, tan humano,

tan atado a tus brazos

como un río a sus montes.

Que si sigue subiendo

no nos veremos nunca:

yo en mi sombra, y ella

loca, suicida, loca,

morirá devorada

por el azul sin nadie.

Llámala, madre, dile

que la amo y la amo

con mil flores de sombra.

(Albán, 1995: 585)

La Enciclopedia de maravillas, como cualquier otra enciclopedia, puede reunir o remitir a diversas imágenes y simbolismos posibles en torno a la figura de la gaviota. Por ejemplo, esta se ha asociado típicamente con el campo semántico de la costa. Su vuelo y envergadura han sido objetos de admiración y poetización. Llama también la atención su manera de alimentarse. Míticamente, los indios lilloet de Columbia británica consideran a la gaviota como "propietaria de la luz del día" (Chevalier y Gheerbrant, 1988: 526). Los marineros han llegado a creer que su presencia en altamar simboliza el alma de un navegante siguiendo el barco donde vivió. Como se verá a continuación, rastros de estas imágenes de la gaviota registradas en las enciclopedias también se presentan en este poema albaniano.
Este poema presenta una métrica clásica isosilábica: Predominan los versos heptasílabos, en los cuales prevalece el versículo (las sílabas tónicas de cada verso no siempre corresponden a la segunda, cuarta y sexta sílaba del heptasílabo regular). Es necesario aplicar sinalefas y hiatos como licencias poéticas para que la medida se ajuste a la métrica constante, a lo largo de todo el poema. No obstante, en el primer verso se presentan dos posibilidades de lectura ya se aplique el hiato, ya la elipsis del verbo. En el primer caso, el ritmo del verso se volvería más lento de modo que se enfatiza la imagen de la "gaviota" suspensa en la corriente del "viento" marino. En el segundo caso, si se aplica la sinalefa, faltaría una sílaba, la cual se vería completa por la elipsis del verbo "va". En consecuencia, la elipsis motivaría la imagen dinámica de vuelo de la "gaviota", sin perjuicio de la claridad del texto, ya que el verbo ("va") se encuentra implícito en el desplazamiento ascensional de esta ave: "Qué alta [va] la gaviota,/ madre, sobre la arena".

Este texto posee como rasgo particular la invocación de la "madre". El sujeto lírico invoca la presencia de esta última a fin de aprehender o contener, con su ayuda, a la "gaviota". Esta empresa, más que la adquisición de la criatura en sí, representa el deseo de la transformación y la ascensión espiritual de este sujeto.

Desde los cuatro primeros versos del poema, la "gaviota" se construye como el objeto del deseo del sujeto lírico; ella es la poseedora de la luz; es el elemento fascinans del misterio. Ella, mediante el símil, es comparada con el "espejo" de los "sueños". En tanto "espejo", la gaviota le refleja a este sujeto la luz, la verdad, el contenido anhelado y profundo de sí: ese "sueño" de lo secreto numinoso que él contempla en la criatura lírica, mientras esta se desplaza sobre el ambiente acuático y terrestre, donde se encuentran él precisamente y su madre. En medio de ambos espacios, se sitúa la "madre" invocada. El vuelo de la criatura lírica representa la posibilidad de acceso del sujeto lírico a un modo de ser trascendente. Su vuelo es la relación incuestionable entre el cielo y la tierra, pues su ligereza simboliza la liberación de la pesadez 
terrenal. En otras palabras, su vuelo es extático y representa un estado espiritual.

De esta manera, la presencia de la "madre" es significativa en este texto. El simbolismo de la "madre" se relaciona tanto con el de la tierra como el del "mar", puesto que los tres resultan "receptáculos de la vida y matrices de la vida" (Chevalier y Gheerbrant, 1988: 674). Su relación con el agua, particularmente, se debe a que ambas contienen las posibilidades totales de un cierto estado de existencia (Guénon, 1946), pues, en este sentido, la vida y la muerte se presentan como correlativas en las dos. El "mar" (léase en él la extensión simbólica del 'agua') y la "madre" son fuentes de armonía y amor cósmicos. La "madre" en sí connota la vital fuerza universal manifiesta: el principio espiritual expreso en lo femenino. Ella es capaz de unir y sostener el universo, ya que representa la "unidad de lo que está manifestado, cualquiera que fuere su nivel de existencia" (Chevalier y Gheerbrant, 1988: 675).

Por ello, el sujeto lírico busca a su "madre", con el fin de que lo acerque y unifique mediante el amor cósmico, al misterio tremendo y fascinante de que ya es partícipe la "gaviota". Alcanzar lo celestial y el vuelo extático como esta criatura significaría para él unificar sus dos naturalezas existenciales: la sagrada y la profana.

En síntesis, la "madre" simboliza la posibilidad de una homologación antropocósmica entre el sujeto lírico y el universo, pues a través de ella aquel alcanzará su regeneración espiritual. Así se podría comprobar desde el verso 1 hasta el 12 .

En estos versos referidos, nótese implícitamente la descripción literaria del escenario marino, así como el límite de los espacios telúrico (las montañas nevadas, enrojecidas por el crepúsculo) y uránico. Este último se cimienta sobre el símbolo del "azul", el cual es, en consecuencia, el indicador de la condición limítrofe entre las experiencias contingentes y vivencias intuitivas del sujeto lírico, ya que este experimenta lo sagrado celestial a partir del aspecto tremendo de la inmensidad.
Por consiguiente, lo "azul" representa el obstáculo y lo indefinido. La inmensidad del cielo y el "mar" provoca en este sujeto el mysterium tremendum capaz de desmaterializar o disolver su forma consciente, lo mismo que el vuelo de la "gaviota" en las alturas. En este sentido, lo blanco de esta ave y lo "azul" de la inmensidad se concilian para representar el desapego de los valores de este mundo y el ascenso del espíritu hacia lo trascendente para conformar un escenario sagrado, "donde se representa la rivalidad de lo inmanente y lo trascendente de la tierra y el cielo" (Chevalier y Gheerbrant, 1988: 164). La significación de estos colores, por tanto, sugiere la trascendencia o la espiritualidad.

El sujeto lírico desea, a partir de su contemplación del vuelo de la 'gaviota' y sus ruegos (obsérvese el predominio de verbos en tiempo presente de los modos imperativo y subjuntivo) a la "madre", la tranquilidad y elevación espiritual, la cual se simboliza con el movimiento del ave: un movimiento de alejamiento de él hacia lo infinito, un dejarse maravillar y ser poseído por lo numinoso (v. 6 ); este poder capaz de despertar en él deseo de pureza y sed de lo suprahumano (Kandinsky, 1954). La contemplación del vuelo de la criatura lírica por parte del sujeto lírico, en definitiva, corresponde a las almas comprometidas con la búsqueda iniciática; la estabilidad emocional del ser que conlleva la liberación de lo divino de la naturaleza humana en medio de la contingencia terrestre. Su vuelo es la promesa de que existe un mundo espiritual.

En este escenario, entonces, lo "azul" y la "madre" son umbrales que separan al sujeto lírico de la Verdad de lo sagrado. No en vano el apóstrofe dirigido a la "madre" se ubica siempre en mitad de los versos (vv. 5, 38 y 42) o las oraciones (vv. 1-2, 30-31).

La única forma posible de acercarse a la "gaviota", según el sujeto lírico es a través del juego y la ronda. Él recurre a la "madre" con una actitud lúdica e infantil, puesto que pretende dialogar con lo invisible, a través de ella o del juego mismo. Con los versos 19-21, a modo de canción infantil, el sujeto 
lírico pretende un acercamiento espontáneo y voluntario con el ave, producto de la crisis existencial que representa la vida profana (“sombras" y vv. 33-34).

Intertextualmente, el poema dialoga, en estos versos (centro ideológico del texto), con el género discursivo denominado: ronda. El polisíndeton de "que" en estos versos articula una expresión más lenta y solemne, similar al de una ronda musical, cuya melodía y tono es constante a lo largo del poema debido a la métrica isosilábica. En dicha expresión, asimismo, los sonidos vocálicos /a/, /e/ y /o/ de las sílabas tónicas de cada verso generan una onomatopeya, que "evoca un ambiente nítido, claro, fresco” (Fernández, 1972: 49).

La ronda posibilita un juego. Uno en donde se propicia la unión de los pares al verse obligados a tomarse de las manos y formar un círculo (el sujeto lírico, su "madre" y la "gaviota"). Todo juego, per se, es un acto de espontaneidad frente a las coacciones del mundo exterior y sensible. Originalmente, el juego se encuentra ligado a lo sagrado ${ }^{10}$; por ello, en este caso, este sujeto desea establecer una ronda, un vínculo con la "gaviota", dado que esta le recuerda el origen cósmico común $\mathrm{y}$, en consecuencia, se asegura a sí mismo un beneficio: la asociación a un rito sagrado (el vuelo), revelado por el juego y su experiencia sagrada profunda.

El sujeto lírico quiere que él y esta ave sean "cómplices" de "blancos juegos". El simbolismo del color blanco reafirma estos “juegos”, justamente, su carácter ritual ${ }^{11}$, por el cual el sujeto lírico se verá involucrado en "las mutaciones del ser, según el esquema clásico de toda iniciación: muerte y renacimiento" (Chevalier y Gheerbrant, 1988: 190). La "gaviota" no solo es "espejo" porque refleja el deseo interior del sujeto lírico ("sueño"), sino porque además fulgura; su color "blanco" es el mismo "color iniciador (...) el color de la revelación, de la gracia, de la transfiguración que deslumbra, despertando el entendimiento al mismo tiempo que transcendiéndolo: es el color de la teofanía" (Chevalier y Gheerbrant, 1988: 192).
Los "blancos juegos" del sujeto lírico, por tanto, constituyen una preparación intuitiva, una relación con su mundo interior; ya que, ante este color, "lo que tenía de desarreglado [este sujeto en su existencia profana] entra en el orden, lo que tenía de defectuoso se embellece y resplandece con toda la luz de una pura y santa vida (PseudoDionisio, 1943: 91). Esto es posible, ya que toda actividad lúdica implica una trasferencia de energía psíquica, de manera que "el jugador coloca en cierto modo su propia libido en la cosa con que juega. De ello resulta que el juego se convierta en una acción mágica que despierta la vida (...) jugar es por tanto un rito de entrada y prepara el camino de la adaptación al objeto real" (Adler, 1957: 102-103). Así, el sujeto lírico, en tanto jugador, busca a su "madre" para formar una ronda, pues se manifiesta o comporta como niño; esto es, un ser que aún no vive plenamente en las circunstancias profanas; un ser, en consecuencia, quien responde más fácilmente al llamado transformativo y regenerador de lo "azul" y lo "blanco".

No es de extrañar, entonces, que el sujeto lírico, en este sentido, se autodefina con los símbolos del "viento" y la "sombra" (vv. 5-8, 22-25 y 30-33). Al definirse metafóricamente como "viento", el sujeto lírico expresa su condición espiritual, él la reconoce, pues en él reside el mismo influjo celestial de la creación, ese mismo hálito que sostiene y compone la naturaleza aérea y luminosa de la "gaviota". Él aspira, indudablemente, en tanto "viento", a la comprensión y vivencia subjetiva de la espiritualidad; esa que solo se alcanzaría siendo "gaviota" ante ese "azul invencible", lo sagrado celeste del mar.

No obstante, el sujeto lírico es en el tiempo histórico profano, aunque comprenda la trascendencia de su espiritualidad (vv. 7-8). La "sombra" da a entender, por un lado, la naturaleza corporal y material de este sujeto, es decir, una sombra física. La "madre" le ha dado el ser y, con él, su "sombra" (vv. 23-25). Sin embargo, esta sugiere, por otra parte, el surgimiento de un nuevo ser. Es notorio este valor cuando el sujeto lírico pretende desprenderse de su "sombra" (vv. 31-33). 
De acuerdo con Jung (1984, 2002), el arquetipo de la sombra constituye el lado más débil e inadaptado de la persona: la crisis de la personalidad consciente. Ella se puede proyectar según los estados de ánimo o impulsos repentinos. El sujeto suele ocultar este aspecto débil o negativo de su personalidad mediante las máscaras (de la voz latina: personnare) o actitudes conscientes que asume ante las diferentes circunstancias de la vida. Así, podría interpretarse que el sujeto lírico desea superar su "sombra" alcanzando, como la "gaviota", una permeabilidad del cuerpo ante la luz, en miras de purificación o salida de las limitaciones de la existencia corporal (vv. 52-54). Este deseo del sujeto lírico justifica la repetición diseminada del imperativo "dile" y la anáfora de "Llámala".

Frente a la posibilidad de este nuevo ser y el vuelo del ave, el sujeto lírico se siente como un ser inadaptado en el mundo contingente del mundo, debido a su imposibilidad de volar (vv. 42-45).

Los deseos más encarecidos del sujeto lírico se enuncian mediante el uso de la conjunción subordinante completiva ("que") y el tiempo presente del modo indicativo, dentro de un acto volitivo (vv. 13-18 y 34-37).

En los versos referidos anteriormente, el sujeto lírico es consciente de su naturaleza sagrada, la cual le ha sido manifiesta, en parte, a través del mysterium fascinans del vuelo de la "gaviota", ya que esta conoce el ámbito celeste (vv. 14-15). Por consiguiente, esta ave representará, aún más, para él, el deseo de situarse con los ritmos cósmicos y armonizarse con ellos, elevarse a las alturas, pues descubre que su naturaleza humana es inacabada. Su existencia comprende la posibilidad de un proceso de perfeccionamiento espiritual ("lámpara") mayor.

Además, la "gaviota" conoce "la segura luz", la cual connota el primer aspecto del mundo informal propio de lo sagrado ${ }^{12}$. Esto es, la intuición del conocimiento sagrado conlleva la disolución de las formas materiales y conscientes del mundo contingente, ya que el ser asciende hasta un nivel de vida humana o un plano cósmico superior a las fuerzas de la "sombra" corporal y sensible. La "gaviota" trae consigo la "luz" y ella misma es "luz"; en consecuencia, ella representa una hierofanía. Esta criatura lírica es el "espejo" que refleja la "luz" cósmica y del espíritu en medio de los destellos aprisionados en la materia profana del mundo (vv. 3-4 y 18). Ella es lumen de lumine: ella lleva e introduce el espíritu humano en el mundo de lo sagrado.

En síntesis, el comprender esta "luz" y a la "gaviota" misma representaría la iniciática iluminación espiritual, el acceso al sumo Conocimiento, lo incognoscible a través de la mente humana, opuesto al conocimiento discursivo y racional, simbolizado en este texto por la "luna"13. Lo sagrado es "segura luz": la expresión de las fuerzas uránicas, la revelación más adecuada de lo numinoso.

Con base en lo anterior, esta ave es descrita por el sujeto lírico como: "loca" y "ciega de lejanías", "azul", "desnuda" y siempre en ascenso. Debido a la altura de su vuelo y naturaleza sagrada, la "gaviota" ha adquirido cualidades de trascendencia ("lejanías"); se ha convertido en akatalepton (aquello que escapa de la explicación racional por medio de los conceptos) a través de su ascenso; así lo expresan los símbolos: "luz", “azul” y "lejanías". Su locura de "azul" al seguir "subiendo" también representa esta desmaterialización, puesto que su "loca" movilidad resulta un escape de las formas comunes $^{14}$ para unificarse con el universo y comprenderlo "como todos los dioses". Su desapego del mundo material ("desnuda") atestigua su inmersión en lo celestial y lo místico indefinido ("azul"). Por ello, el sujeto lírico la compara con una "rosa", dadas las connotaciones de poderío e instrucción espiritual, que él contempla en aquella gracias a su desnudez (vv. 38-39). Compruébese esto en los versos 26-29, $38-41$ y $46-51$.

Justamente en los versos 46-51, nótese que la "gaviota" se encuentra en riesgo de ser devorada por el "azul". Esta acción no representa una annihilatio de la criatura, sino más bien la desmaterialización experimentada por causa de lo energicum de lo sagrado cósmico a que ella se ha acercado o de que ella es parte ya.

El poema culmina con la antítesis de la dual naturaleza humana del sujeto lírico (vv. 52-54). El símbolo de la "flor" sugiere las virtudes 
espirituales y la espera de un nuevo estado espiritual de este sujeto. Su fe en lo sagrado lo conduce a la iluminación espontánea y expresión misma de lo inexplicable, sintetizados en el símbolo de la criatura lírica a lo largo de todo el poema, como la "Fuerza de una convicción que hace de ese proceso de introspección [del sujeto lírico] el principio de todo proyecto poético, la experiencia de la verticalidad [y] de la inmensidad del cosmos" (Chen, 2007: 92).

\section{4. "EI lobo"}

El viejo lobo sabe

que la luna no existe.

Que la noche es el negro

espejismo de un viaje

sin retorno: aullar...

Y por eso camina

sobre el polvo del tiempo,

dejando un leve rastro

de sed desembozada.

Arrastrando una larga

polvareda de vidas,

de amores que incendiaron

los bosques de sus ojos,

de presas reasumidas

en la sangre y la ausencia.

$\mathrm{Y}$ el viejo lobo sigue

bajo el sol que no espera,

sobre la estrella pálida

que es la nieve en el mundo.

Marchando más allá

de su sombra y del viento.

El viejo lobo,

el lobo que dejó

campanarios vencidos

tañendo sin regreso.

El viejo lobo sabe

que la montaña no es una montaña,

sino una estela que alguien

extendió ante su vida,

una torre de espinas

que ha inventado el silencio,

una nave que va

de la luna a la luna, que no existe.

Y por eso va ciego

aunque todo lo mire.
Y por eso está quieto aunque todo lo ande. Y por eso se muere aunque todo lo vive. $Y$ por eso en las noches de las lunas perfectas, cuando todos los lobos aúllan incendiados:

el hocico afinándose hacia un punto de estrellas.

Y las lentas cabañas que la luna sostiene colgando de los bordes de los riscos del viento, jaspean indefensas

entre nieve y silencio,

el viejo lobo mira

un mundo que no existe, una luna que nunca ha nacido, un invierno que nunca le ha mordido la frente, y no puede morir porque tampoco hay muerte.

(Albán 1995: 877)

En este poema, el sujeto lírico observa el comportamiento del "lobo"; inclusive, conoce lo que este "sabe". En el verso 1, lo mismo que en el 16, 22, 23 y 52, el "lobo" es caracterizado por el epíteto enfático "viejo". La vejez, como todo símbolo, es coincidentia oppositorum, pues, por un lado, representa la sabiduría, virtud, experiencia y reflexión que solamente la madurez permite (vv. 6-15); la longevidad es "una imagen imperfecta de la inmortalidad [...ya que...] ser un viejo es existir desde antes del origen; es existir después del fin de este mundo" (Chevalier y Gheerbrant, 1988: 1052). Esto último es posible, ya que "Lo anciano, lo ancestral, lo antiguo reviste carácter sagrado, cualquiera que sea el objeto o la persona así cualificados" (Chevalier

30 y Gheerbrant, 1988: 94). Por otra parte, la vejez también simboliza el debilitamiento y la declinación de la vida, el acercamiento a la muerte, la miseria y la desaparición. Tal tensión de significados se presenta en la criatura lírica de este poema al ser calificado como "viejo". 
El "lobo" lírico es presentado en medio de un ambiente nocturno ("noche", lo "negro"15). Aunque se menciona a la "luna", esta no refuerza dicho ambiente, ya que según el acto reflexivo del "lobo" (v. 1, 26): "la luna no existe".

La "noche" se presenta como un "negro espejismo". Ella anuncia la muerte y los engaños del mundo y la vida (vv. 4-5), esos que quizá el "lobo" teme por estar 'viejo'. Desde el verso 1 hasta el 15 , el sujeto lírico, por tanto, comienza a asociar la actitud "vieja" de la criatura lírica a la de un ser humano consciente de su realidad de desconsuelo y soledad en el mundo, así como intuitivo del misterio terrible y fascinante de lo sagrado.

La "noche" es metaforizada como “espejismo". Este último recibe, como epíteto metafórico, el adjetivo calificativo: "negro". Así, la "noche", en tanto "negro espejismo", representa un ocultamiento u oscurecimiento de la Verdad en la existencia trágica en la tierra, pues la realidad del mundo es también un "espejismo" para el sujeto lírico. La asociación de este color con el "espejismo" advierte, asimismo, la pasividad absoluta de la vida terrenal: El "negro" hermético es símbolo de un estado de muerte consumado, un duelo sin esperanza y el retorno al caos. La percepción sensible del "negro" evoca la nada, las tinieblas terrenales de la "noche" (vv. 6-7), la aflicción (vv. 8-9), la melancolía (vv. 12-13), el pesimismo, el infortunio, la confusión (vv. 10-11), la desolación y el desorden en medio de la vida cotidiana (vv. 14-15); en resumen, "la angustia, la tristeza, lo inconsciente y la muerte (Chevalier y Gheerbrant, 1988: 749) que el "lobo" en tanto "viejo" teme.

El ambiente gélido, descrito metafóricamente a partir del símbolo de la "nieve", tanto en la segunda como la tercera estrofa del poema, connota un estancamiento del mundo (vv. 18-19), el rotundo y constante peso de las circunstancias cotidianas (al inicio del poema el ambiente era nocturno). Ahora, como lo indica la prosopopeya, se está "bajo el sol que no espera" y cae sobre la criatura lírica, (re) engañando, debilitando y paralizando, inclusive, su conciencia y espíritu (vv. 20-21); aunque motivando, al mismo tiempo, su intuición.
Con base en lo susodicho, se evidencia un ámbito desolador y desconcertante, sobre el cual se funda una visión pesimista de la realidad terrestre, pues el tiempo y el espacio, según el sujeto lírico, limitan a la criatura lírica (vv. 22-25).

En consecuencia, este sujeto ve en el "viejo lobo" un ser que sufre. Aquel siente que la existencia de este es lamentable, aunque por su vejez conoce intuitivamente los misterios de la vida y la suya propia. "El viejo lobo sabe" que la existencia es un tránsito "Y por eso camina (...) Arrastrando (...) sigue (...) Marchando más allá/ de su sombra y del viento". Él "sabe" que su existencia, en gran parte, es "polvo" (vv. 7, 8-9 y 11). Él se encuentra sujeto a los ciclos vitales, los cuales potencian su temor sobre el devenir, la fugacidad y decrepitud de su ser, en un mundo fenomenológico de apariencias, simbolizado a través de la extinción rápida del sonido de los "campanarios". Puede interpretarse esto en los versos $16-19$ y $22-25$.

La criatura lírica continúa "marchando" en medio de su hábitat ("montaña") y reflexionando. Entre los versos 26 y 31, el sujeto lírico está seguro de que contempla en el "lobo" a un ser con plena conciencia reflexiva y facultad intuitiva, capaz de intuir lo misterioso en el mundo, pues este último aparece representado como un espacio antitético (v. 27), espacio de reunión de contrarios propicio para la vivencia subjetiva del misterio y lo sagrado, donde lo aparente de lo real ("la montaña") sugiere un encadenamiento de percepciones y significaciones que anuncian cómo el "lobo" vive y experimenta la realidad.

Esta construcción de la realidad del mundo según la vive y "sabe" el "lobo", se presenta en el poema a través de una metáfora descriptiva o impresionista ${ }^{16}$, donde la "montaña", en tanto elemento real, se vincula primero con "estela"; segundo, con "torre de espinas"; y, tercero, con "nave". Al metaforizar la "montaña" como "una estela que alguien/ extendió ante su vida", se sugiere la capacidad intuitiva del "lobo" para saber los misterios profundos y sagrados que se presentan frente a la existencia de su ser. En tanto, "una torre de espinas/ que ha inventado el silencio", la "montaña" se representa como 
un espacio de pruebas penosas donde la criatura lírica experimenta la sensación de nulidad ("su silencio"). Esta interpretación es válida en tanto se lea que la "torre de espinas" ha inventado el "silencio". No obstante, estos dos versos se construyen sobre una ambigüedad; por lo tanto, se puede leer también que el "silencio" ha inventado la "torre de espinas". Si se considera esta última lectura, se sugeriría que el "silencio", en tanto efecto de la capacidad reflexiva e intuitiva del "lobo", provoca en esta criatura la vivencia de la ascensión a la "montaña" como un proceso doloroso, pues debe enfrentarse a su débil naturaleza material ("viejo") y su sabiduría y vivencia profunda del arquetipo del anciano sabio; es decir, de la eternidad, pues:

El solo hecho de haber envejecido, sin desaparecer enteramente, evoca ya una suerte de vínculo con las fuerzas supratemporales de conservación. Que un ser haya resistido al desgaste del tiempo se siente como una prueba de solidez, de autenticidad, de verdad. Alcanza así en las profundidades misteriosas lo que está en la fuente de la existencia y de lo cual participa en medida privilegiada (Chevalier y Gheerbrant, 1988: 94).

Sobre este arquetipo, expone Jung:

El "anciano sabio" aparece en sueños como mago, médico, sacerdote, maestro, profesor, abuelo o como cualquier persona dotada de autoridad. El arquetipo del espíritu en figura de hombre, de gnomo o de animal se presenta en situaciones en que haría falta visión de las cosas, comprensión, buen consejo, decisión, previsión, etc., pero no se puede conseguir por propios medios. El arquetipo compensa ese estado de carencia espiritual con contenidos que rellenan el espacio vacío (1984: 200).

Por último, al metaforizarse la "montaña" como "una nave que va/ de la luna a la luna, que no existe", se sugiere la necesidad de la criatura lírica de superar su soledad en la senda aparente, temporal y penosa del mundo. La única posibilidad de esta superación es su marcha ascensional a la "montaña". Tal ascensión simboliza acceder y comprender la estructura sagrada trascendente y representada, opuesta al ambiente gélido y nocturno (vv. 3-4, 19, $33,51,58)$.
La "montaña" posibilita la ascensión espiritual, en términos de identificación con el cosmos, pues en ella habitan los misterios "en cuanto centro de las hierofanías atmosféricas y de numerosas teofanías, participa del simbolismo de la manifestación. Es así el encuentro del cielo y la tierra, la morada de los dioses y el término de la ascensión humana. Vista desde lo alto, aparece como la punta de una vertical; es el centro del mundo; vista desde abajo, desde el horizonte, aparece como la línea de una vertical, el eje del mundo, pero también la escala, la pendiente a escalar" (Chevalier y Gheerbrant, 1988: 722). De ahí que la "montaña" es el camino y la prueba iniciáticos para el "lobo". Ella es "torre", en tanto permite el ascenso a un conocimiento más intuitivo y espiritual. Este es un viaje dificultoso ("espinas"), pues angustia y confronta al "lobo" con sus condicionamientos materiales y sensibles ("presas", "bosque"). La "montaña" como "nave" refuerza para el sujeto lírico la idea de que el adentramiento iniciático es una travesía espinosa, pues solo así se alcanzará ascender por el eje del mundo hasta la vida espiritual.

Lo monstruoso y sublime de la "montaña" desolada es, justamente, el misterio en grado superlativo, ya que este espacio poético, recóndito y solitario, permite al sujeto lírico y al "lobo" experimentar una conmoción y oscilación de su ser interior hacia un misterio profundo y un reconocimiento de su nulidad terrenal. Al respecto puede interpretarse desde el verso 34 hasta el 45.

En torno a estos versos anteriores, se instaura, enfáticamente mediante la anáfora y la conversión, un régimen nocturno ${ }^{17}$; lo diurno (vv. 16-17) es solamente transitorio. En el régimen nocturno, la naturaleza es vista como refugio tranquilo contra la dimensión temporal y sus estragos sobre los cuerpos materiales; las tinieblas se convierten en noche serena (Durand, 1971, 1993), en noche cósmica (Chevalier y Gheerbrant 1988). En esta noche no se busca rehuir del tiempo, sino eternizarse con las intuiciones del devenir. Por ello, en los susodichos versos, el "lobo" busca lo intemporal y sagrado en el seno de la fluidez del tiempo (considérese el tránsito desde lo diurno 
hasta lo nocturno), donde la noche cósmica es propedéutica necesaria del día: es una indudable promesa de aurora (Durand, 1982).

No es casual que la criatura lírica, en este caso, sea un "lobo", ya que este, precisamente, es un animal nocturno "Porque ve en la noche, es símbolo de luz" (Chevalier y Gheerbrant, 1988: 652). Él, durante su ascensión a la "montaña" en medio de la "noche", experimenta una vivencia extática (v. 36), en la cual se adapta y asimila a una visión totalizadora (vv. 35, 37, 39) y a un instante presente (vv. 32, 34, 36, 38) revelador de las oposiciones de sí y del mundo, mientras es consciente del destino trágico de su vejez, su posible muerte y lo ilusorio e irreal del mundo (tómese la "luna" como metonimia del mundo) "que no existe". Por tanto, en los oxímoros de la estrofa anteriormente citada, se observan dos estructuras sintéticas ${ }^{18}$ : la armonización de los contrarios y la estructura dialéctica o contrastante.

Por su experiencia profunda de "viejo lobo", la criatura lírica no puede compartir las experiencias contingentes colectivas. Él no es un animal gregario. Para el sujeto lírico, el "lobo" va solo, es un ser solitario, mas no arbitrariamente: El "viejo lobo" busca la experiencia de lo sagrado mediante la desintegración de actitudes vitales.

Para este sujeto, esta criatura desea avanzar hacia el mysterium, deseo que no comulga con las experiencias colectivas de la comarca, ya que "en las noches/ de las lunas perfectas,/ cuando todos los lobos/ aúllan incendiados", él se aparta para adentrarse en su propio mundo ("montaña", "bosque") y encontrar, quizá, una manifestación de lo misterioso, conducente a la iluminación espiritual. Su aullido "incendiado", entonces, es distinto del de los demás. El suyo propio simboliza el deseo profundo de liberarse de su condición y condicionamiento materiales, "afinándose/ hacia un punto de estrellas": buscando la ascesis de su espíritu. Su aullido "incendiado" es metáfora del simbolismo del fuego, de esa "llama que sube hacia el cielo [y] representa el impulso hacia la espiritualización" (Diel, 1976: 37).

El sujeto lírico interpreta el comportamiento social de la comarca como el porqué del apartamiento del "lobo". Su necesidad de un conocimiento mayormente intuitivo y espiritual lo empuja a aislarse. En este sentido, él supone que esta criatura llega a experimentar un límite, una especie de cerca divisoria entre el espacio profano común ("cabañas") - ese espacio que no volverá a pisar ya igual (vv. 23.25) - y misterioso suyo, latente de convertirse en sagrado ("montaña"). Se trata de un límite entre lo racional del ordenamiento del espacio humano general y la espontaneidad ambigua y misteriosa de la naturaleza del "bosque". El sujeto lírico considera que el "lobo" experimenta un escepticismo, puesto que desconfía de todo cuanto implica vivir en el mundo sensible y detenidamente engañoso (v. 51). Esto podría comprobarse desde el verso 46 hasta el 51.

En síntesis, la experiencia dialéctica de armonización de los contrarios y la visión escéptica del mundo permiten expresar algo más que la individualidad consciente del "lobo", a partir de sus experiencias vitales, según el sujeto lírico. Es decir, develan la necesidad del "lobo" por abandonar el colectivo modus vivendi cotidiano, con el objetivo de despertar, mayormente, el núcleo de su facultad intuitiva ("sabe", "mira") y, mediante tal, encontrar y descubrir lo misterioso, terrible y fascinante durante su marcha por la "nave" penosa del mundo ("montaña", "bosque").

Para el sujeto lírico, pues, el 'lobo' no participa de las representaciones colectivas de la jauría; es decir, de las creencias y supuestos básicos sobre la naturaleza de los objetos materiales, el mundo y la conducta de la vida compartida por los miembros de la manada, impuesta por las presiones instintivas de sobrevivencia (vv. 12-15). Las experiencias colectivas de un mundo fenomenológico obligan a interpretar el mundo solo como un espacio de donde se extrae lo necesario para satisfacer tales demandas fisiológicas ("presas"), antes que permitir la interpretación o percepción de las manifestaciones de lo sagrado y, en consecuencia, la participación de cada una de las criaturas de la comarca, lo mismo que el "lobo", como sujetos participantes, en iguales condiciones, de la Creación. 
En definitiva, la criatura lírica, de acuerdo con la contemplación del sujeto lírico, camina solitaria, alejada del mundo y la comarca, en medio de la "montaña" y la "noche", experimentado ante lo sublime y cósmico de estas su deseo de trascender lo meramente terrenal, adentrarse y adquirir un conocimiento intuitivo y suprasensible, que le permita un acercamiento significativo y revelativo con lo misterioso. Él interpreta el internamiento del "lobo" en la "montaña" como un ahondamiento en lo sagrado, una afirmación de su búsqueda y trascendencia espirituales, así como una liberación de las dimensiones funestas del espacio y el tiempo, a lo largo de todo este poema (vv. 52-58).

\section{Consideraciones finales}

El buey, la gaviota y el lobo, en tanto criaturas y motivos poéticos, despiertan la experiencia tremenda y fascinante de lo sagrado en el sujeto lírico de la Enciclopedia de maravillas. Para este, adentrarse en la naturaleza significa emprender una búsqueda existencial e intuitiva de lo sagrado en diálogo siempre con la creación numinosa y el desciframiento del cosmos. Acudiendo al pensamiento de Zambrano, se podría afirmar que el sujeto lírico de estos poemas "se mira desde lo que le rodea. Y todo, los árboles y las piedras, le mira y, sobre todo, aquello que está sobre su cabeza y permanece fijo sobre sus pasos, como una bóveda de la que no puede escapar: el firmamento y sus huéspedes resplandecientes" (1992: 34).

Por un lado, en "El buey", se identifica un fuerte deseo del sujeto lírico por el conocimiento provisto a través de la intuición sobre la conciencia racional. Se siente, así, una necesidad por el Ser desde el plano del conocimiento. Se exhorta a la defensa de una existencia trascendental en medio de las situaciones materiales y temporales cotidianas.

Por otro lado, se observa una identificación de este sujeto con "El lobo", en tanto aquel interpreta la actitud y cada acto de esta criatura lírica como un signo de lo misterioso terrible y fascinante, a medida que este animal se interna, solitario y apesadumbrado por su edad, en la montaña. En todo momento, el sujeto lírico canaliza en el lobo su deseo de obtener un conocimiento y una vida mayormente intuitiva y espiritual, partiendo desde el mundo profano hacia el axis mundi, en este caso, la montaña. Este poema constituye un ejemplo del trayecto de acercamiento hacia lo sagrado.

Por último, el sujeto lírico contempla en "La gaviota" la forma como un ser intuitivo, que vive en la plenitud espiritual, se mueve libremente en el ámbito celestial, participando del misterio terrible y fascinante, representados a través de los simbolismos de la luz y el cielo. Él invoca a su madre, para que sea ella quien le ayude a alcanzar a aquella criatura y pueda, como esta, sobreponerse a los obstáculos materiales y contingentes del mundo profano que lo distancian de obtener un nivel de conocimiento, existencia y plenitud más intuitivos y trascendentes; en otras palabras, obtener una significativa transformación y ascensión espirituales.

En los tres casos, el sujeto lírico ve en estos animales el deseo intuitivo de búsqueda de lo numinoso, pues ellos son claro ejemplo de la condición cósmica en el ámbito natural, allende el ser humano, quien se ve mediado por la socialización de un espacio materialista, cada vez más desacralizante. Estas criaturas le revelan a este sujeto, en definitiva, su misma condición dual y la de cualquier otro ser: creado con materia cósmica tendiente a volverse profana y obediente a los instintos, pero dotado de esencia trascendental.

\section{Notas}

1. En la edición de este poema, en el tomo I de la Enciclopedia de maravillas, se omite el uso de la coma para aislar el vocativo (RAE 2011). Para efectos de este estudio, se procede a agregarla.

2 Según Chevalier y Gheerbrant, se puede observar en el simbolismo del ojo: "uno de los grados del conocimiento, tal vez utilizado en el sentido de intuición (...) sentido preracional [sic] de la comprehensión intuitiva de los primeros principios filosóficos, y sentido post-racional de la 
comprehensión intuitiva de la verdad mística supraracional" (1988: 772).

Chevalier y Gheerbrant afirman: "La tierra se opone simbólicamente al cielo como (...) la oscuridad a la luz (...) La tierra es la substancia universal (...), el caos primordial" (1988: 992).

Aportan Chevalier y Gheerbrant: "el cedro del Líbano aparece como emblema de la grandeza, la nobleza, la fuerza y la perennidad" (1988: 269).

Exponen Chevalier y Gheerbrant sobre la semilla: "Su simbolismo se eleva sin embargo por encima de los ritmos de la vegetación para significar la alternancia de la vida y la muerte, de la vida en el mundo subterráneo y la vida a plena luz, de lo no manifestado y la manifestación” (1988: 538-539).

Una de las categorías de la dimensión mecánica del símbolo (Durand 1993) es precisamente el nivel verbal. En este, los gestos inmediatos son capital representación figurativa; es decir, la expresión corporal es entendida como verbo, como "inconsciente reflejo del cuerpo vivo" (Durand 1993: 19), en el nivel actancial; por ejemplo: la danza y la mímica previas a la escritura.

Chevalier y Gheerbrant expresan: "En el combate del cielo y la tierra, azul y blanco se alían contra rojo y verde (...) Unos y otros constituían un teatro sagrado, donde se representaba la rivalidad de lo inmanente y lo transcendente, de la tierra y el cielo" (1988: 164).

Según López-Casanova (1994), un modelo compositivo sintético se articula cuando se parte de unidades explicativas y de carácter condensador hacia una base-afirmación ubicada hacia el final del texto.

Afirman Chevalier y Gheerbrant: "se considera la niebla predecesora de las revelaciones importantes: es el preludio de la manifestación" (1988: 752).
Afirma Eliade: "en los ritos de iniciación, el blanco es el color de la primera fase, la de la lucha contra la muerte" (1982: 32).

Chevalier y Gheerbrant exponen sobre el simbolismo de la luz: "Por ejemplo, se puede uno preguntar si la luz como 'aspecto final de la materia que se desplaza a una velocidad limitada y la luz de que hablan los místicos tienen algo común, aparte de ser un límite ideal y un término' (...) Nos orientamos hacia el símbolo, en cambio, al considerar la luz como primer aspecto del mundo informal. 'Dejándonos atraer por ella entramos en un camino que parece poder conducir más allá de la luz, es decir, más allá de toda forma, pero también más allá de toda sensación y noción”” (1988: 663).

Dicen Chevalier y Gheerbrant: "La luna es símbolo de conocimiento indirecto, discursivo, progresivo, frío" (1988: 658).

Sobre el simbolismo del loco, Chevalier y Gheerbrant apuntan: "Todo iniciado parece loco por algún aspecto de su comportamiento, que escapa a las normas comunes. 'La sabiduría iniciática parece locura para el buen sentido vulgar'” (1988: 654).

Presentan Chevalier y Gheerbrant sobre el color negro: "Instalado bajo el mundo, lo negro expresa la pasividad absoluta, el estado de muerte consumado e invariante entre las dos noches blancas donde se operan, en sus costados, los pasajes de la noche al día y del día a la noche. El negro es pues color de duelo, no como el blanco, sino de una manera más abrumadora" (1988, p. 747).

De acuerdo con Fernández (1972), la metáfora descriptiva o impresionista obedece a la estructura: A, b, b', b", b"'..., donde A corresponde al elemento o plano real y b a cada uno de los planos evocados, referidos siempre a aquel, entrelazados por la aposición.

En términos generales, el régimen nocturno, según Durand (1971, 1993), es la dimensión simbólica que indica la tendencia al recogimiento e intimidad del ser humano. Todas las interpretaciones de estas estructuras se darán desde las categorías nocturnas, pues el lenguaje es una entidad doble y en su hermenéutica prima el lado nocturno, oscuro, profundo y simbólico que penetra en la intimidad de la vida y la subjetividad. profanas, las más espontáneas, las más exentas de toda finalidad consciente; todas derivan de este origen" (1988: 610). 
como dos de las estructuras sintéticas del régimen nocturno. Por la primera entiende la manifestación de una energía móvil que permite la adaptación y la asimilación en una visión totalizadora que organiza el contenido del saber en un sistema, a través de las analogías y las correspondencias perceptivas o simbólicas. En la segunda, la síntesis ya no es una unificación, sino que la coherencia resguarda las distinciones y oposiciones, al conformar la trama de la obra donde se enfrentan las ilusiones y esperanzas humanas, y el destino inhumano o infrahumano; así se domestifica al tiempo.

\section{Referencias bibliográficas}

Adler, Gerhard. 1957. Études de psychologie jungienne. Ginebra: George Becker.

Albán, Laureano. 1995. Enciclopedia de maravillas. Tomos I, II y III. Pittsburg, Estados Unidos: International Poetry Forum.

Campos, Ronald. 2013. "El buey en el imaginario y la literatura costarricenses”. En: Káñina 37 (1): 15-31.

Chen, Jorge. 2007. Del sosiego luminoso y serenidad metafísica en Mariana Sansón Argüello. León, Nicaragua: UNAN.

Chevalier, Jean y Alain Gheerbrant. 1988. Diccionario de los símbolos. Barcelona: Herder.

Chinchilla, Kattia. 2010. Conociendo la mitología. San José: Universidad de Costa Rica.

Diel, Paul. 1976. El simbolismo en la mitología griega. Barcelona: Labor.

Durand, Gilbert. 1971. La imaginación simbólica. Buenos Aires: Amorrortu.
Durand, Gilbert. 1982. Las estructuras antropológicas de lo imaginario. Madrid: Taurus.

Durand, Gilbert. 1993. De la mitocritica al mitoanálisis. Figuras míticas y aspectos de la obra. Barcelona: Anthropos.

Eliade, Mircea. 1981. Lo sagrado y lo profano. Barcelona: Labor.

Eliade, Mircea. 1982. El chamanismo y las técnicas arcaicas del éxtasis. México: Fondo de Cultura Económica.

Fernández, Pelayo. 1972. Estilística. Madrid: Porrúa.

Guénon, René. 1946. Aperçus sur l'initiation. París: Traditionnelles.

Jung, Carl. 1984. Arquetipos e inconsciente colectivo. Barcelona: Paidós.

Jung, Carl. 2002. Obra completa. Los arquetipos y lo inconsciente colectivo. Madrid: Trotta.

Kandinsky, Vassily. 1954. Du spirituel dans l'art. París: De Beaune.

López-Casanova, Arcadio. 1994. El texto poético. Teoría y metodología. Salamanca: Ediciones Colegio de España.

Otto, Rudolf. 1925. Lo santo. Lo racional y lo irracional en la idea de Dios. Madrid: Revista de Occidente.

Pseudo-Dionisio, Areopagita. 1943. Obras completas. París: Montaigne. 
Real Academia Española. 2011. Ortografía de la lengua española. México: Planeta.
Zambrano, María. 1992. El hombre y lo divino. Madrid: Siruela.

\section{(ब) $\odot \Theta$}

Este obra está bajo una licencia de Creative Commons Reconocimiento-NoComercial-SinObraDerivada 4.0 Internacional. 
